\title{
Utilization of Biotechnology on Some Forest Trees in Turkey
}

\author{
Esra Nurten Yer ${ }^{1}$, Sezgin Ayan ${ }^{1 \Xi}$ \\ ${ }^{1}$ Kastamonu University, Faculty of Forestry, Silviculture Department, TR-37100 Kuzeykent, \\ Kastamonu, Turkey \\ ${ }^{\vee}$ Corresponding author: e-mail: sezginayan@gmail.com
}

\section{Citation:}

YER EN, AYAN S 2014 Utilization of Biotechnology on Some Forest Trees in Turkey. South-east Eur for 5 (2): 93-102. DOI: http://dx.doi.org/10.15177/seefor.14-12

\begin{abstract}
Background and Purpose: Raw wood material requirements are increasing with rapid population growth both in Turkey and in the world. In order to supply deficit for closure of forest products, productivity and quality of production should be improved. Basic ways to increase efficiency in forest production involves silvicultural implementations and classical tree breeding studies. Genetic variation can be increased by utilizing the existing diversity. Thus, new combinations can be obtained and we can raise efficiency using some selection strategies. At this point, biotechnological methods are required to meet the genetic material. Studies of forest tree breeding are a slow process due to the size of the genome and the length of the tree life span. Biotechnological applications in forest trees provide many important benefits in terms of time saving and reducing cost when compared to classical breeding studies. Sustainable forestry practices are gaining rapid acceleration via biotechnology and modern sciences practices. In this study, for some forest tree species in Turkey, the evaluated biotechnology methods included; 1 - tissue culture and clonal propagation, 2- molecular marker applications, 3- marker assisted selection and breeding, 4-genomic and proteomic studies, 5- genetic modification and genetic engineering applications.
\end{abstract}

Conclusions: In this study, the works were carried out on forest tree breeding/propagation in Turkey and it was mainly focused on vegetative production techniques with 25 broadleaves and 9 conifer taxa, which were possible to express. Molecular genetic studies were carried out on 12 broad leaves taxa and 9 conifer taxa; genetic transformation studies were conducted on poplar species. Thus, it might be suggested that a combination of biotechnological tools and traditional propagation methods will ensure advantage for the development of forest-tree species.

Keywords: tree breeding, biotechnology, sustainable forestry, tissue culture, genomics studies

\section{INTRODUCTION}

In vitro breeding, gene transfer and markerassisted breeding approaches of biotechnology contributed greatly on genetical improvement of forest trees to the level comparable with sophistication of ordinary genetic improvement applied for agricultural varieties [1]. It is described in FAO documents that forest biotechnology comprises three main field as follows; using 
molecular genetic markers to get information on genetic futures of populations and genetic base of traits, using advanced breeding technologies to produce consistent high quality planting rootstock at low price and in order to offer new economic future or ecological value, genetic engineering of trees [2]. Due to big size and long growing times of trees, the advance of forest tree breeding is a slow and challenging process. Recently, forest genomics has offered new medium for studying adaptation in trees. The gene technology for forestry has been used to solve the primary environmental issues, to produce cheap renewable energy, to specify relevant genes for the adaption of forest tree. Especially, forest trees' genes having growth future such which is resistant to disorders, herbicide and environmental stresses and wood future such as reducing lignin and increasing cellulose attracts much attention. The usage of modern genotyping technologies that are a highly beneficial medium to analyze effect of dense forestation process, to specify genes that control amazing phenotypes designates allelic assortment for the candidate genes in forest tree populations and measures adaptive allelic assortment for thousands of genes at the same time [3].

Forest biotechnology is related to a wide range of modern procedures practicable for agricultural and forest science and only some part of these procedures are relevant to genetic engineering. Biotechnology term in silviculture comprises all perspectives of propagation of tree and cloning of plant, genotyping of DNA, manipulation and transfer of gene [4]. Conventional breeding depends more intensely on sexual crosses and monitoring trait phenotypes. In order to ensure more precise or a more sweeping results than the results that can be obtained only using phenotypic selection, biotechnology surrounds different procedures that entails one or more laboratory or greenhouse intensive steps. Such procedures may contribute to saving time, reducing expenses or achieving new goals.

Tissue culture, clonal breeding, genetic markers, gene transferring and genomic technologies are extensively used biotechno- logical practices. The key determinants of this quick development process are promoting powerful and applicable techniques in the biotechnology field and completing genome sequences of certain forest tree forms. Such techniques and studies have contributed exceptionally to the project of propagation of forest trees. As a consequence of the newly found gene regions, gene transfers studies, etc.; creating genetic maps, clone breeding and improving the quality of wood in forest trees were performed. Approximately 45000 gene sources have contributed greatly to genomic investigation by sequencing poplar tree (Populus trichocarpa) genome. Therefore, QTL analysis, genetic modifications and EST sequencing facilitate finding new genes. Additionally, such studies assist in developing specific robust tree forms for specific environmental conditions [5].

Biotechnological procedures having or probably having specific impact on forest tree propagation and the position of the research in Turkey have been presented in the present study. Namely, for some woody taxa in Turkey, the biotechnology methods: 1- tissue culture and clonal propagation, 2- molecular marker applications, 3 - marker assisted selection and breeding, 4 - genomic and proteomic studies, 5 - genetic modification and engineering applications, were evaluated.

\section{BIOTECHNOLOGY PRACTICES FOR FOREST TREE PROPAGATION}

Biotechnology can be assessed in three main fields as follows; traditional propagation, molecular genetics, and genetic transformation. Traditional propagation has been used to develop plants for centuries. Over the last two decades, developments in molecular genetics were introduced into the scientific circles and they completed the tools that have been used by traditional breeders. There are two distinct subcategories in molecular genetics. The first one is "Non-controversial technologies", the plant genome is not altered. This category includes; molecular markers used for DNA fingerprinting 
and MAS (QTL mapping and association genetics); sequence analysis (genomic DNA, cDNA libraries (ESTs) that helps to discover the gene; and in vitro breeding such as somatic embryogenesis. The second in this category is "controversial technologies" that includes recombinant DNA and gene transfer practices. Genetic engineering makes it possible to include new genes among the existing, elite genotypes [6].

Biotechnology comprises change and development of genetic capabilities of plants through different tissue culture and genetic engineering practices. Biotechnology is a technology that is widely practiced and which has a big potential to reduce expenses of production and protection through the energy obtained from non-renewable energy resources as well as to increase agricultural productivity [7].

New biologic inventions in previous years have offered scientists many options, especially in silviculture, to acquire this knowledge.

When we focus on forest trees, biotechnology collaborates with various freestanding disciplines such as vegetative breeding, namely; cuttings, organogenesis, somatic embryogenesis, maturation and micro-propagation; molecular genetics, namely, molecular markers, cloned plant genes and quantitative trait loci and genetic transformation namely; somatic hybridization, gene transfer methods, gene transfers, prospects and limitations [8].

\section{Vegetative Propagation (VP)}

Vegetative breeding influences forest trees' developments by using available genotypes for the production of new genotypes valuable in terms of trade. Cutting and in-vitro methods are the major vegetative breeding procedures of forest trees; organogenesis and somatic embryogenesis. Based on their purpose and other similar things, the techniques used differ among different species and within species. The field tests have great importance due to probable unsteadiness in in-vitro regenerated plants [8].

\section{Molecular Genetics (MG)}

In recent decades, big developments in molecular genetics of plants enabled the use of it for tree breeding. The possible effect of it relies on the usage of molecular markers and the cloning and characterization of genes and their promoters that manage biological processes' improvement and function [8].

\section{Genetic Transformation (GT)}

The traditional gene transfer technique was used effectively in hybridization, however, as it is already known, this technique is only applicable for sexually suitable tree species and it takes many years for its implementation. Such drawbacks can be avoided using the new gene transfer method [8].

In Table 1, a framework for current possible applications of biotechnology for certain forest tree in Turkey can be found.

TABLE 1. Potential applications of biotechnology (VP - vegetative propagation, MG - molecular genetics, GT - genetic transformations) on some forest tree species in Turkey

\begin{tabular}{|c|c|c|c|c|}
\hline \multirow{2}{*}{ Family } & \multirow{2}{*}{ Tree species } & \multicolumn{3}{|c|}{ Propagation type } \\
\hline & & VP & MG & GT \\
\hline \multirow{10}{*}{ Pinaceae } & Pinus sylvestris L. [9-11] & & $\mathbf{x}$ & \\
\hline & Pinus nigra L. [9-15] & $\mathbf{x}$ & $\mathbf{x}$ & \\
\hline & Pinus brutia Ten. $[9,16-23]$ & $\mathbf{x}$ & $\mathbf{x}$ & \\
\hline & Pinus pinea L. $[9,11]$ & & $\mathbf{x}$ & \\
\hline & Pinus halepensis Mill [17] & & $\mathbf{x}$ & \\
\hline & Pinus pinaster Ait [9]. & & $\mathbf{x}$ & \\
\hline & Picea orientalis L. Link. [24-28] & $\mathbf{x}$ & $\mathbf{x}$ & \\
\hline & Picea abies L. Karst [29] & $\mathbf{x}$ & & \\
\hline & Abies spp.[30-32] & & $\mathbf{x}$ & \\
\hline & Cedrus libani (A. Rich.) [33, 34]. & & $\mathbf{x}$ & \\
\hline
\end{tabular}


TABLE 1. Potential applications of biotechnology (VP - vegetative propagation, MG - molecular genetics, GT - genetic transformations) on some forest tree species in Turkey - continuation

\begin{tabular}{|c|c|c|c|c|}
\hline \multirow{2}{*}{ Family } & \multirow{2}{*}{ Tree species } & \multicolumn{3}{|c|}{ Propagation type } \\
\hline & & VP & MG & GT \\
\hline \multirow{7}{*}{ Fagaceae } & Fagus sylvatica L.[35, 36] & & $\mathbf{x}$ & \\
\hline & Fagus orientalis Lipsky $[35,37]$ & & $\mathbf{x}$ & \\
\hline & Quercus petraea ((Mattuschka) Lieb.) [38-40] & $\mathbf{x}$ & $\mathbf{x}$ & \\
\hline & Quercus robur L. [38-40] & $\mathbf{x}$ & $\mathbf{x}$ & \\
\hline & Quercus ithaburensis Decne subsp. [38-40] & $\mathbf{x}$ & $\mathbf{x}$ & \\
\hline & Quercus cerris L. [38- 40] & $\mathbf{x}$ & $\mathbf{x}$ & \\
\hline & Castanea sativa Mill. [41, 42] & $\mathbf{x}$ & & \\
\hline \multirow{5}{*}{ Salicaceae } & Populus nigra L. [43-45] & & $x$ & \\
\hline & Populus spp. [45-48] & & $\mathbf{x}$ & $\mathbf{x}$ \\
\hline & Populus tremula L. $[45,49,50]$ & $\mathbf{x}$ & $\mathbf{x}$ & \\
\hline & Salix alba L. $[51,52]$ & & $\mathbf{x}$ & \\
\hline & Salix excelsa S.G. Gmel. $[51,52]$ & & $\mathbf{x}$ & \\
\hline \multirow{4}{*}{ Tiliaceae } & Tilia platyphyllos Scop. [53] & $\mathbf{x}$ & & \\
\hline & Tilia tomentosa Moench. $[38,54]$ & $\mathbf{x}$ & & \\
\hline & Tilia rubra DC. $[54,55]$ & $\mathbf{x}$ & & \\
\hline & Tilia cordata Mill. [54] & $\mathbf{x}$ & & \\
\hline \multirow{4}{*}{ Betulaceae } & Betula pendula Roth.[29] & $\mathbf{x}$ & & \\
\hline & Betula medvediewii Reg. [56] & $\mathbf{x}$ & & \\
\hline & Alnus glutinosa (L.) Gaertn. [57-59] & $\mathbf{x}$ & & \\
\hline & Corylus colurna L. [10] & $\mathbf{x}$ & & \\
\hline \multirow{4}{*}{ Cupressaceae } & Sequoia sempervirens (Lamb) Endl. $[60,61]$ & $\mathbf{x}$ & & \\
\hline & Juniperus communis L. [62] & $\mathbf{x}$ & & \\
\hline & Juniperus foetidissima Wild. [63] & $\mathbf{x}$ & & \\
\hline & Juniperus excelsa Bıeb. [63] & $\mathbf{x}$ & & \\
\hline Oleaceae & Fraxinus oxycarpa Wild. [38] & $\mathbf{x}$ & & \\
\hline Fabaceae & Robinia pesudoacacia L. [38] & $\mathbf{x}$ & & \\
\hline Elaeagnaceae & Eleagnus angustifolia L. $[38,64]$ & $\mathbf{x}$ & & \\
\hline Aceraceae & Acer negundo L. [38] & $\mathbf{x}$ & & \\
\hline Platanaceae & Platanus orientalis L. [38] & $\mathbf{x}$ & & \\
\hline Altingiaceae & Liquidamber orientalis Mill. [38, 65-68] & $\mathbf{x}$ & $\mathbf{x}$ & \\
\hline Myrtaceace & Eucalyptus spp. $[69,70]$ & $\mathbf{x}$ & & \\
\hline Cornaceae & Cornus mas L. [71] & $\mathbf{x}$ & & \\
\hline Taxaceae & Taxus baccata L. [72] & $\mathbf{x}$ & & \\
\hline Ulmaceae & Ulmus minor Mill. [10] & $\mathbf{x}$ & & \\
\hline Lauraceae & Laurus nobilis L. [73-75] & $\mathbf{x}$ & & \\
\hline Anacardiaceae & Pistacia lentiscus var. chia [76] & $\mathbf{x}$ & & \\
\hline
\end{tabular}




\section{DISCUSSION}

Due to the big size and long generation periods of trees, until now, the development of forest tree has been a slow and challenging process. In conformity with tree propagation and forestry programs, it is important that forest biotechnology meets the industry requirements for forest products while enabling protection of natural forests mining [2].

It is required to implement comprehensive precipitated - propagation programs to reforest and develop current forest-tree species. It is predicted that a combination of biotechnological tools and traditional propagation methods will ensure advantage for the development of foresttree species [77].

In addition to biotechnology's economic advantages for silviculture such as the increase in production, cost effectiveness for consumers and modified trees for allowing easy processing or other production values, the advantages of biotechnology contribute to the protection of biodiversity and to the decreasing global warming issue [78].

Using such technologies will allow forest trees to be more tolerant to abiotic and biotic stresses, gene expression for rapid growth and modification in wood structure.

Additionally, the usage of these technologies on research has some benefits such as escalated genetic gain per generation by an improved selection in traditional propagation programs, quick application of genetically developed tree species for plantations and better understanding of the genes that manage commercially crucial futures. Such trees will carry the silviculture to a different position in terms of productivity and quality. Additionally, when trees are modified to grow on arid or saline soils that were not suitable for growing before, the created forests can improve the wood production and at the same time contribute to the watershed protection and sequester carbon for the mitigation of climate change and similar things [4].

\section{CONCLUSIONS}

Phenotypic assessments require a lot of time and investments and in turn they don't ensure information on the gene's variation that manages adaptive variations. A vast number of molecular marker technologies is available, however, most of these technologies measure neutral or high conservative genetic variations of limited adaptive value. In order to assess the vast number of adaptive genes and prospective trees for in-situ conservations, it is required to develop quick and elucidative identifying methods. In order to study adaptation in trees, genomics offers new mediums. In order to specify DNA sequences and to genotype a vast number of individuals, forest geneticist may use technologies that are automated, highly effective, quick and productive [79].

One of the areas where biotechnological methods were used recently was the implementation of biotechnology in forest trees. Biotechnological techniques were widely used on important subjects such as obtaining resistance to diseases and herbicide of forest trees, elevating tree growth rates and developing resistance to environmental stresses such as drought, salinity, climate change and similar things. Additionally, reducing lignin and increasing cellulose to develop wood, attracts much attention. This issue is discussed through the application processes, positive and negative impacts of transgenic trees on the environment and it was also tried to be procured on the auditing legislations related to the studies [80].

In short, in addition to the advantages of using biotechnology in silviculture such as the increase in production, cost effectiveness for consumers and modified trees for allowing easy processing or some production values, the advantages of biotechnology are contributing to the protection of biodiversity and decreasing global climate changes. 


\section{REFERENCES}

1. MERKLE SA, DEAN JF 2000 Forest tree biotechnology. Curr Opin Biotech 11 (3): 298302. DOI: http://dx.doi.org/10.1016/509581669(00)00099-9

2. WHETTEN RW, KELLISON R 2010 Research Gap Analysis for Application of Biotechnology to Sustaining US Forests. J Forest 108 (4): 193-201

3. YER EN, BALOĞLU MC, AYAN S 2014 Forest genomics for forest tree breeding and gene conservation. In: Book of Abstracts of the Third International Symposium on Biology of Rare and Endemic Plant Species (BIORARE-2014), Antalya, Turkey, 19-23 April 2014,

4. WALTER C, MENZIES M 2010 Genetic modification as a component of forest biotechnology. In: ElKassaby YA, Prado JA (eds) Forests and Genetically Modified Trees. Food and Agriculture Organization of the United Nations, Rome, Italy, pp 3-17

5. ERTUĞRUL F, ÇIÇEK E, AYDIN Y 2011 Forest genetics and biotechnology. SDU Faculty of Forestry Journal 12: 155-162

6. FARNUM P, LUCIER A, MEILAN R 2007 Ecological and population genetics research imperatives for transgenic trees. Tree Genet Genomes 3 (2): 119133. DOI: http://dx.doi.org/10.1007/s11295-0060063-z

7. KURT O, ŞAVŞATLI Y 2005 A general view to plant biotechnology. OMU J Fac Agric 20 (3): 126-133

8. HAGGMAN H 1991 Application of biotechnology to forest tree breeding. Silva Fenn 25 (4): 270-279. DOI: http://dx.doi.org/10.14214/sf.a15624

9. ŞENTÜRK F 1997 Çam (Pinus sp.) Türlerinde Genetik Polimorfizmin DNA Markır Teknolojisi ile Tanımlanması (in Turkish). MSc thesis, Gebze Institute of Technology, Gebze, Turkey, $55 \mathrm{p}$

10. COŞKUN S 2002 Batı Karadeniz Bölgesinde Bazı İbreli ve Yapraklı Türlerin Çelikle Köklenmesi Üzerine Araştırmalar (in Turkish). Batı Karadeniz Ormancılık Araştırma Müdürlüğü, Bolu, Turkey, Teknik Bülten 7

11. IKTÜEREN \$̧ 1976 Propagation some of the indigenous pines by cuttings (in Turkish with English summary). Ormancilık Araştırma EnstitüsüYayınları, , Ankara, Turkey, Teknik Bülten 78: 20 p. URL: http://web.ogm.gov.tr/birimler/ arastirma/icanadolu/Dökümanlar/bultenler/0078. pdf (5 May 2014)
12. VELIOĞLU E, ÇENGEL B, IÇGEN Y, KANDEMIR G, ALAN M, KAYA Z 2002 Comparison of existing genetic diversity in Black Pine (Pinus nigra Arnold sub. pallasiana (Lamb.) Holmboe) Seed Stands, Seed Orchards and Plantations using molecular markers (in Turkish with English summary). Forest tree seeds and tree breeding research directorate, Ankara, Turkey, 11: 190, $23 \mathrm{p}$

13. VELIOĞLU E, ÇENGEL $B$, IÇGEN Y, KANDEMIR G, ALAN M, KAYA Z 2004 Determination of genetic diversity of Anatolian Black Pine (Pinus nigra Arnold) populations in Kırklareli-Kasatura Bay Nature conservation Area by Molecular Markers (in Turkish with English summary). Forest tree seeds and tree breeding research directorate, Ankara, Turkey, 15: 265, 27 p

14. ÖZKURT Z, YILDIRIM T, ÖNDE S, KAYA Z 2008 Induction of embryogenic tissue from immature Zygotic Embryos in Pinus nigra J.F. Arnold subsp. nigra var. caramanica (Loudon) Businsky. Turk J Bot 32 (3): 179-183

15. ÇENGEL B, TAYANÇ Y, KANDEMIR G, VELIOĞLU E, ALAN M, KAYA Z 2012 Magnitude and efficiency of genetic diversity captured from seed stands of Pinus nigra (Arnold) subsp. pallasiana in established seed orchards and plantations. New Forest 43 (3): 303-317. DOI: http://dx.doi. org/10.1007/s11056-011-9282-8

16. VELIOĞLU E, IÇGEN Y, ÇENGEL B, ÖZTÜRK H, KAYA $Z 2002$ Comparison of existing genetic diversity in Turkish Red Pine (Pinus brutia Ten.) Seed Stands, Seed Orchards and Plantations using molecular markers (in Turkish with English summary). Forest tree seeds and tree breeding research directorate, Ankara, Turkey, 10: 189, $22 \mathrm{p}$

17. TOZKAR CÖ, SERTAÇ Ö, KAYA Z 2009 The phylogenetic relationship between populations of marginally and sympatrically located Pinus halepensis Mill. and Pinus brutia Ten. in Turkey, based on the ITS-2 region. Turk J Agric For 33: 363-373. DOI: http://dx.doi.org/10.3906/tar-081126

18. iÇGEN Y, KAYA Z, ÇENGEL B, VELIOĞLU E, ÖZTÜRK $H$, ÖNDE S 2006 Potential impact of forest management and tree improvement on genetic diversity of Turkish red pine (Pinus brutia Ten.) plantations in Turkey. Forest Ecol Manag 225 (13): 328-336. DOI: http://dx.doi.org/10.1016/j. foreco.2006.01.009 
19. YAHYAOĞLU Z, ÜÇLER AÖ 1993 Kızılçam (Pinus brutia Ten.) farklı BAP ve sakaroz konstrasyonlarının in-vitro koşullarında embriyo gelişimi üzerine etkileri. In: Bakanligi 0 (ed) Papers of the International Symposium on Pinus Brutia Ten., Marmaris, Turkey, 18-23 October 1993. Secretariat of the Organizing Committee, Ankara, Turkey, Vol. 1, pp 254-263

20. DOĞAN B 1997 Kazdağı yöresi doğal kzılçam (Pinus brutia Ten.) populasyonlarında izoenzim çeşitliliği (in Turkish). Ege Ormancılık Araştırma Enstitüsü Müdürlüğü, İzmir, Turkey, Teknik Bülten 10: 43 p

21. KAYA Z, NEALE DB 1993 Random Amplified Polymorphic DNA (RAPD) Polymorphisms in Pinus nigra var. pallasiana and Pinus brutia. Turk J Agric For 17: 295-306

22. LiSE Y 2000 The Impact of Anthropogenic Factors on The Composition of Genetic Variation on Pinus brutia Ten. Populations Determined By DNA Markers. MSc thesis, Middle East Technical University, Ankara, Turkey

23. içGEN Y 2002 Tohum Meçcereleri ve Bahçeleri Tohumlarıla Kurulan Pinus brutia Ten. Ormanlarında Genetik Yapılanmanın Moleküler Markörler Yardımıyla Belirlenmesi. MSc thesis, Middle East Technical University, Ankara, Turkey, $130 \mathrm{p}$

24. TURNA I 1996 Determination of Genetic Structure of Oriental Spruce (Picea orientalis (L.) Link.) populations using by Isozyme Analysis. MSc thesis, Karadeniz Technical University, Trabzon, Turkey

25. GÜLSOY AM, TEMEL F, GÜLSOY AD, KAYA Z 2010 The Phylogenetic analysis of Picea orientalis populations from northeastern Turkey with respect to non-coding TRN regions of chloroplast genome. In: Book of Abstracts of The International Symposium on Biology of Rare and Endemic Plant Species (BIORARE Symposium), Fethiye, Turkey, 2629 May 2010

26. TEMEL F, ÖZDILEK A, KANDEMIR G, ÖLMEZ Z, KAYA Z 2014 Tolerance to bark beetle damage in Picea orientalis: Molecular evidence. In: Book of Abstracts of the Third International Symposium on Biology of Rare and Endemic Plant Species (BIORARE-2014), Antalya, Turkey, 19-23 April 2014

27. ERKULOĞLU ÖS, ERON Z 1985 Studies on the Rooting of Stem Cuttings of Eastern Spruce (Picea orientalis L.) Seedlings (in Turkish with English summary). Ormancılık Araştırma Enstitüsü Yayınları,Ankara, Turkey, Teknik Bülten 155: 47 p. URL: http://web.ogm.gov.tr/birimler/arastirma/ icanadolu/Dökümanlar/bultenler/0155.pdf
28. YAHYAOĞLU Z 1980 Doğu Ladini (Picea orientalis L.)'in Vejetatif Yolla (Çelikle) Üretilmesi Olanakları Üzerine Araştırmalar. Doçentlik Tezi, Karadeniz Technical University, Faculty of Forestry, Trabzon, Turkey

29. YAHYAOĞLU Z 1986 Picea abies L. Karst ve Betula pendula Roth doku kültürü tekniği yardımıyla vejetatif yolla üretilmesi olanakları. In: International Plant Breeding Congress, , Izmir, Turkey, 15-17 October 1986

30. TAYANÇY, ÇENGEL B, KANDEMIR G, VELIOĞLU E 2013 Genetic Diversity and Phylogenetic Classification of Fir (Abies spp.) Populations Distributed in Turkey (in Turkish with English summary). , Forest tree seeds and tree breeding research directorate, Ankara, Turkey, Teknik Bülten 33: 41 p. URL: http://www. ortohum.gov.tr/Tekbul/TB33.pdf

31. ATEŞ MA, DEĞIRMENCI FÖ, TAYANÇ Y, ÇENGEL B, KANDEMIR G, VELIOĞLU E, KAYA Z 2010 The sequence data on non-coding TRN region of chloroplast genomes of Turkish Firs indicating the speciation from a single ancestral Fir. In: Book of Abstracts of The International Symposium on Biology of Rare and Endemic Plant Species (BIORARE Symposium), Fethiye, Turkey, 26-29 May 2010

32. KAYA Z, SKAGGS A, NEALE DB 2008 Genetic differentiation of Abies equi-trojani (Asch. \& Sint. Ex Boiss) Mattf. Populations from Kazdağı, Turkey and the genetic relationship between Turkish Firs belonging to the Abies nordmanniana Spach Complex. Turk J Bot 32: 1-10

33. GÜLBABA A G, ÖZKURT N 2002 Isoenzyme Diversity in Cedar (Cedrus libani A. Rich) Populations Sampled from the Bolkar Mountains (in Turkish with English summary). Eastern Mediterranean Forestry Research, Tarsus, Turkey, Teknik Bülten 14: $30 \mathrm{p}$

34. KAYIHAN GC 2000 Cedrus libani A. Rich. Populasyonlarındaki Genetik Yapılanmanın RAPD Markörler Tarafından Belirtilmesi (in Turkish). MSc thesis, Middle East Technical University, Ankara, Turkey, $83 \mathrm{p}$

35. GAILING O, WUEHLISCH GV 2004 Nuclear marker (AFLPs) and Chloroplast Microsatellites Differ between Fagus sylvatica and F. orientalis. Silvae Genet 53 (3): 105-110

36. KANDEMIR G, TAYANÇ Y, ÇENGEL B, VELIOĞLU E 2014 Genetic variation of European beech (Fagus sylvatica) populations in Turkey. In: Book of Abstracts of the Third International Symposium on the Biology of Rare and Endemic Plant Species (BIORARE-2014), Antalya, Turkey, 19-23 April 2014 
37. KANDEMIR GE, KUŞ E, TAYANÇ $Y$, ÇENGEL B, VELIOĞLU E 2013 Genetic Variation of Oriental Beech (Fagus orientalis) Populations in Artvin Area. In: International Caucasian Forestry Symposium, Artvin, Turkey, 24-26 October 2013. URL: https:// ekonferans.artvin.edu.tr/index.php/ICFS/ICFS/ paper/viewFile/171/139

38. KIZMAZ M 1995 Studies on the vegetative propagation techniques of some broadleaved tree species (in Turkish with English summary). Turkish Forestry Research Institute, Ankara, Turkey, Technical Bulletin 262: 61 p. URL: http://www.ogm. gov.tr/Baskanliklar/DislliskilerEgitimveArastirma/ Documents/Teknik-Bultenler/0262.pdf

39. DIZKIRICI A, KAYA Z, AKTAŞ C, ÇETINER Ç 2010 Determination of phylogenetic and evolutionary structure within Quercus genus that are native to Turkey. In: Book of Abstracts of The International Symposium on Biology of Rare and Endemic Plant Species (BIORARE Symposium), Fethiye, Turkey, 26-29 May 2010

40. KAYA Z 2012 Türkiye'deki meşe türlerinin moleküler sistematiği: evrimsel ilişkiler ve doğal melezlemenin türleşmedeki rolü. TUBiTAK Projects, 1 April 2009-1 April 2012

41. ŞAN B, SEZGIN M, DUMANOĞLU H, KÖKSAL Ai 2007 Somatic embryogenesis from immature cotyledons of some European chestnut (Castanea sativa Mill.) cultivars. Turk J Agric For 31: 175-179

42. SOYLU A, ERTÜRK Ü 1999 Researches on micropropagation of chestnut. In: Salesses G (ed) Proceedings of the Second International Symposium on Chestnut, Bordeaux, France, 19-23 October 1998. International Society for Horticultural Science, Leuven, Belgium, Acta Horticulturae 494: 247-254

43. TAŞKIRAN B, KAYA Z 2014 Genetic control of cellulose, lignin and glucose contents in European black poplar (Populus nigra L.) populations from Turkey. In: Book of Abstracts of the Third International Symposium on the Biology of Rare and Endemic Plant Species (BIORARE-2014), Antalya, Turkey, 19-23 April 2014

44. ZEYBEK E, YILDIRIM K, KAYA Z 2014 Seasonal changes of cold-related antioxidant enzyme activities in black poplar (Populus nigra) individuals. In: Book of Abstracts of the Third International Symposium on the Biology of Rare and Endemic Plant Species (BIORARE-2014), Antalya, Turkey, 19-23 April 2014
45. GÖZÜKIRMIZI N 1998 Kağıtlık hammadde nitelikleri biyogenetik olarak geliştirilmiş kavak (Populus) klonlarının etüd ve araştırılması. TubitakMam, Gebze, Turkey, $123 \mathrm{p}$

46. ÖZDILEK A, YÜCER Ç, KAYA Z 2014 Allelic differences in the flowering locus $\mathrm{T} 2$ gene among poplar species. In: Book of Abstracts of the Third International Symposium on the Biology of Rare and Endemic Plant Species (BIORARE-2014), Antalya, Turkey, 19-23 April 2014

47. YILDIRIM K, ZEYBEK E, KAYA Z 2014 Production of bark storage proteins associated to delaved leaf senescence and drought tolerance in Populus nigra. In: Book of Abstracts of the Third International Symposium on the Biology of Rare and Endemic Plant Species (BIORARE-2014), Antalya, Turkey, 19-23 April 2014

48. IPEKÇI $Z$, OĞRAŞ T, ALTINKUT A, BAYROVIC $K$, KAZAN K, GÖZÜKIRMIZI N, BOYDAK M, TANK T, AKALP T, ÖZDEN Ö, ÇALIKOĞLU M, TUNÇTANER K, TULUKÇU M, BALKAN H, TANRIYAR H 1999 Reduced leaf peroxidase activity is associated with reduced lignin content in transgenic poplar. Plant Biotechnol 16 (5): 381-387. DOI: http://dx.doi. org/10.5511/plantbiotechnology. 16.381

49. GÖZÜKIRMIZI N, BARJROVIÇ K, IPEKÇI Z, BOYDAK $\mathrm{M}$, AKALP T, TUNÇTANER $\mathrm{K}$, BALKAN H, TANRIYAR $H$, ÇALIKOĞLU M, OĞRAŞ T, ÖZDEN Ö, TULUKÇU M, TANK T 1998 Genotype differences in direct plant regeneration from stem explants of Populus tremula in Turkey. J Forest Res-JPN 3 (2): 123-126. DOI: http://dx.doi.org/10.1007/BF02760313

50. TOPLU F, TULUKCU M, TUNÇTANER K 1991 Titrek Kavak (Populus tremula L.)'in Çelikle Üretilmesi Üzerine Araştırmalar. Kav. Ve Hız. Gel. Tür., İzmit, Turkey, Teknik Bülten 154

51. DEĞIRMENCI FÖ, ACAR P, KARAHAN FA, KAYA $Z$ 2014 Genetic structures of Salix alba and Salix excelsa clone banks assessed by microsatellite DNA Markers. In: Book of Abstracts of the Third International Symposium on the Biology of Rare and Endemic Plant Species (BIORARE-2014), Antalya, Turkey, 19-23 April 2014

52. ACAR P, ÖZER YT, KAYA Z 2014 Phylogenetic relationships of some Turkish Salix species inferred from matK sequence data. In: Book of Abstracts of the Third International Symposium on the Biology of Rare and Endemic Plant Species (BIORARE-2014), Antalya, Turkey, 19-23 April 2014 
53. ÜÇLER AÖ, MOLLAMEHMETOĞLU N 2001 In vitro plantlet regeneration from mature embryos of linden (Tilia platyphyllos Scop.) and multiplication of its Buds. Turk J Agric For 25: 181-186

54. ÖZPAY Z 1998 Ihlamur'un (Tilia L.) Tohum ve Çelikle Yetiştirilmesi İmkanların Üzerine Araştırmalar. Orman Bakanlığı Batı Karadeniz Ormancılık Araştırma Enstitüsü, Bolu, Turkey, Teknik Bülten 2

55. YAHYAOĞLU Z 1995 Kafkas Ihlamuru (Tilia rubra D.C) embriyolarında in-vitro koşullarında fidan elde edilmesi (in Turkish). Turk J Agric For 19: 231235

56. YAHYAOĞLU Z, ÖLMEZ G, ÖLMEZ Z 2000 Betula medvediewii Reg. doku kültürü teknikleri ile üretilmesi. In: XV. Ulusal Biyoloji Kongresi, Ankara, Turkey, 5-9 September 2000

57. AYAN $S$, YAHYAOĞLU $Z$, GERÇEK $V$, ŞAHIN $A$, SIVACIOĞLU A 2006 The Vegetative Propagation Possibilities of Black Alder [Alnus glutinosa subsp. barbata (C. A. Mey.) Yalt.] by Softwood Cuttings. Pak J Biol Sci 9 (2): 238-242

58. ATASOY H, KÜÇÜK M 1989 Kızılağaç (Alnus glutinosa) çeliklerinin köklendirilmesi üzerine çalışmalar. Ege Forestry Research Institute, Ankara, Turkey, Teknik Yayın 36-39

59. GERÇEK V, AYAN S, ŞAHIN A, AKSU V 2005 The Vegetative Production facilities for Bearded-alder (Alnus glutinosa subsp. barbata L.), Ministry of Forests, the Institution of Eastern Black Sea Forestry Studies, Ministry of the Environment and Forests Publication number: 179, Directorate of Eastern Black Sea Forestry Research, Publication number: 23, Technical Bulletin Publication number: 18, Trabzon, Turkey

60. GERÇEK V, ŞAHIN A, S. AYAN 2002 Effects of Different Hormone Concentrations on Plantlets Growing of Sequoia Sempervirens (Lamb.) Endl. (in Turkish with English summary). Gazi University Kastamonu Education Journal 10 (1): 173-180

61. EYÜBOĞLU AK, ATASOY $H$, GERÇEK V, ŞAHIN A 1997 Sahil Sekoyası (Sequoia sempervirens (D.) Don.) Çelikle Üretilmesi. Trabzon, Turkey Teknik Bülten 1

62. KOÇER ZA 2005 In vitro growth and development of common juniper (Juniperus communis) from bud explants. MSc thesis, Middle East Technical University, Faculty of Arts and Sciences, Ankara, Turkey

63. KESKIN S 1992 Kokulu Ardıç (Juniperus foetidissima Wild.) ve Boylu Ardıç (Juniperus excelsa Bieb.)'ın Çelikle Üretilmesi. Ormancılık Araştırma Enstitüsü Yayınları, Ankara, Turkey, Teknik Bülten 233
64. KALYONCU IH, ERSOY N, YILMAZ M 2008 A research on the effect of some hormone and relative Humidity levels on rooting of softwood top cuttings of Russian Olive (Elaeagnus angustifolia L.) determined by the selection of breeding. SDU Faculty of Forestry Journal 3 (1): 9-18

65. ÖZDILEK A, OR M, ÇENGEL B, KANDEMIR G, TAYANÇ Y, VELIOĞLU E, KAYA Z 2012 Molecular phylogeny of relict-endemic Liquidambar orientalis Mill based on sequence diversity of chloroplast-encoded matK gene. Plant Syst Evol 298 (2): 337-349. DOI: http://dx.doi.org/10.1007/ s00606-011-0548-6

66. ALAN M, VELIOĞLU E, EZEN T, ŞIKLAR S, ÖZTÜRK H 2014 Diversity of Some quantitative characters of Oriental sweetgum (Liquidambar orientalis Mill.) In: Book of Abstracts of the Third International Symposium on Biology of Rare and Endemic Plant Species (BIORARE-2014), Antalya, Turkey, 19-23 April 2014

67. GENÇ A 1999 Sığla ağacı (Liquidambar orientalis Mill) doku kültürü tekniği ile üretilmesi. Ege Forestry Research Institute, İzmir, Turkey, Teknik Bülten 14: $41 \mathrm{p}$

68. GENÇ A 2000 Sığla Ağacı (Liquidambar orientalis Mill.)'nin Doku Kültürü Tekniği ile Üretilmesi. Ege Forestry Research Institute, İzmir, Turkey, Teknik Bülten 14

69. GÜLBABA AG 1997 Vegetative propagation of Eucalyptus by Cuttings (in Turkish with English summary). DOA Dergisi 3: 17-37

70. ÖZKURT N 1999 Bazı Okaliptüs (Eucalypus camaldulensis Dehn.) Klonlarının In vitro Klonal Çoğaltılması. DOA Dergisi 5: 27-48

71. FEYZIOĞLU F, AYAN S 2002 The Effects of Different Plant Growth Regulators on the Planlet Development of Dogwood (Cornus mas L.). Journal of Science of Gazi University 15 (2): 533556

72. COŞKUN S 1998 Adi porsuk (Taxus baccata L.)'ın Çelikle Üretilmesi Üzerine Araştırmalar. Batı Karadeniz Ormanclık Araştırma Müdürlüğü, Bolu, Turkey, Teknik Rapor 1

73. BOZA A 2013 Defne'nin (Laurus nobilis L.) Doku Kültürü Yöntemiyle Üretilme Olanakları. Araştırma Bülteni, İzmir, Turkey

74. PARLAK S 2007 Defne (Laurus nobilis L.)'nin Tohumla ve Çelikle Ürtimi Esaslarının Belirlenmesi Üzerine Araştırmalar (in Turkish). PhD thesis, Karadeniz Technical University, Institute of Natural Sciences, Trabzon, Turkey, $92 \mathrm{p}$ 
75. PARLAK S 2013 Clonal Propagation of Bay tree (Laurus nobilis L.) Using Cutting. In: Book of Abstracts of the International Symposium on In Vitro Culture and Horticultural Breeding, Coimbra, Portugal, 2-7 June 2013

76. PARLAK S, ALBAYRAK N 2011 Sakı (Pistacia lentiscus var. chia)'nin Aşlama Yoluyla Çoğaltılması, Ege Forestry Research Institute, İzmir, Turkey, Teknik Bülten 49: $51 \mathrm{p}$

77. TZFIRA T, ZUKER A, ALTMAN A 1998 Forest-tree biotechnology: Genetic transformation and its application to future forests. Trends Biotechnol 16 (10): 439-446. DOI: http://dx.doi.org/10.1016/ S0167-7799(98)01223-2
78. SEDJO RA 2001 Biotechnology in forestry, considering the costs and benefits. Resources for the future 145: 10-12

79. KRUTOVSKII KV, NEALE DB 2001 Forest genomics for conserving adaptive genetic diversity. Food and Agriculture Organization of the United Nations, Rome, Italy, pp 1-26

80. FILIZ E, ÇIÇEK E, KULAÇ Ş 2011 Transgenic Forest Trees (in Turkish with English summary). Artvin Çoruh Üniversitesi Orman Fakültesi Dergisi 12 (2): 232-240 